\title{
Effect of 1-deoxynojirimycin on the Replication of Baculoviruses, Bombyx Mori Nucleopolyhedrovirus and Autographa Californica Multiple Nucleo- polyhedrovirus
}

\author{
Kyung-Don Kang, Joo Sung Park ${ }^{3}$, Yong Seok Cho, Young Shik Park, Jae Yeon Lee, Kyo Yeol Hwang, \\ Won Jeong Yuk, Shizuo George Kamita ${ }^{1}$, Koichi Suzuki ${ }^{2}$, and Su-Il Seong ${ }^{3, *}$ \\ R\&D Center, Biotopia Co., Ltd., Chuncheon, 200-883, Republic of Korea \\ ${ }^{1}$ Department of Entomology, University of California, Davis, CA 95616, USA \\ ${ }^{2}$ Department of Agro-Bioscience, Faculty of Agriculture, Iwate University, Morioka 020-8550, Japan \\ ${ }^{3}$ Department of Life science, The University of Suwon, Hwaseong 445-743, Republic of Korea
}

(Received 09 June 2011; Accepted 30 August 2011)

1-Deoxynojirimycin (DNJ) is an alkaloid that is found at relatively high concentrations in mulberry leaf and tissues of the silkworm, Bombyx mori. DNJ is a well known inhibitor of $\alpha$-glucosidase, an enzyme that is involved in the early stages of the $N$-linked glycoprotein synthesis pathway. $\alpha$-Glucosidase activity in the cell extract from $B$. mori-derived $\mathrm{Bm} 5$ cells showed approximately 40-fold less sensitivity to DNJ than $\alpha$ glucosidase activity in the cell extract from Spodoptera frugiperda-derived Sf9 cells. The replication of $B$. mori nucleopolyhedrovirus (BmNPV) was not inhibited when it was propagated in $\mathrm{BmN}$ cells that were grown in medium containing up to $10 \mathrm{mM}$ DNJ. In contrast, the replication of Autographa californica multiple NPV (AcMNPV) was reduced by $67 \%$ when it was propagated in Sf9 cells that were grown in medium containing $10 \mathrm{mM}$ DNJ. The viability of $\mathrm{Bm5}$ and $\mathrm{Sf9}$ cells that were grown in medium containing up to $10 \mathrm{mM}$ DNJ was not affected. Our results suggested that the reduced replication of AcMNPV was the result of the higher sensitivity of $\alpha$-glucosidase activity in Sf9 cells to DNJ.

Key words: 1-Deoxynojirimycin, Bombyx mori nucleopolyhedrovirus, BmNPV, Baculovirus, $\alpha$-Glucosidase inhibitor

\footnotetext{
*To whom the correspondence addressed

Department of Life science, The University of Suwon, Hwaseong 445-743, Republic of Korea.

Tel: +82-31-220-2483; Fax: +82-31-220-2484;

E-mail: sseong@suwon.ac.kr
}

\section{Introduction}

Glycosylation is an essential process in eukaryotic cells that attaches glycans to proteins and other biomolecules. In many proteins, appropriate glycosylation is essential for proper folding, authentic biological activity, and/or for normal protein stability. The most common types of glycoproteins are $N$-linked (glycans attached to a nitrogen of asparagine or arginine) and $O$-linked (glycans attached to the hydroxyl oxygen of serine, threonine, tyrosine, hydroxylysine or hydroxyproline). $\alpha$-Glucosidase and mannosidase are the key enzymes involved in the $N$ linked glycosylation pathway (Francis et al., 2002). The first step of $N$-linked glycosylation generally involves the transfer of $\mathrm{Glc}_{3} \mathrm{Man}_{9} \mathrm{GlcNAc}_{2}$ (a 14-sugar precursor formed by 3 glucose, 9 mannose, and $2 \mathrm{~N}$-acetylglucosamine molecules) to a nascent protein in the endoplasmic reticulum (ER). Subsequently, the attached $\mathrm{Glc}_{3} \mathrm{Man}_{9} \mathrm{GlcNAc}_{2}$ is processed by glycosidases such as $\alpha$-glucosidase I, $\alpha$-glucosidase II, $\alpha$-mannosidase I, $\alpha$ mannosidase II, and glycosyltransferases such as acetylglucosaminyltransferase I (Ren et al., 1997). The initial steps in the processing of complex oligosaccharides occur in the ER lumen and involve the removal of the terminal glucose of $\mathrm{Glc}_{2} \mathrm{Man}_{9} \mathrm{GlcNAc}_{2}$ by $\alpha$-glucosidase I. Subsequently, $\alpha$-glucosidase II removes the next two glucose residues and $\alpha$-mannosidase I removes one mannose residue. The resulting glycoprotein precursor $\left(\mathrm{Man}_{8} \mathrm{GlCNAc}_{2}-\right.$ protein) moves to the Golgi complex where three more mannose residues are removed by $\alpha$-mannosidase I found within the Golgi. $N$-acetylglucosamine is then attached by $N$-acetylglucosaminyltransferase I and subsequently the 
terminal mannose residues are removed by $\alpha$-mannosidase II. The product, $\mathrm{GlcNAc}_{2} \mathrm{Man}_{3} \mathrm{GlcNAc}_{2}$-protein can be further processed by various enzymes to generate more complex oligosaccharide structures.

1-Deoxynojirimycin (DNJ) is a naturally occurring alkaloid that inhibits glycosidases such as $\alpha$-glucosidase I and $\alpha$-glucosidase II that are involved in the early processing steps of $\mathrm{Glc}_{3} \mathrm{Man}_{9} \mathrm{GlcNAc}_{2}$ (Moremen et al., 1994). Relatively high concentrations of DNJ are found in the leaves of mulberry trees and in silkworm, Bombyx mori (Asano et al., 2001), a caterpillar that feeds exclusively on mulberry. DNJ can also be purified from the culture medium of microorganisms including some species of Bacillus and Streptomyces (Kim et al., 2011). DNJ can inhibit $\alpha$-glucosidase activity in the small intestine of man and other mammals. By inhibiting this $\alpha$-glucosidase activity the amount of free glucose that is generated after a meal is reduced. This reduction in free glucose results in a reduction in the rate of glucose uptake and corresponding reduction in blood glucose levels after a meal. DNJ also functions as an antiviral of enveloped viruses, such as Hepatitis B virus (HBV), Hepatitis C virus (HCV), and bovine virus diarrhea virus (BVDV) (Dwek et al., 2002). Since glycoproteins play important roles in the attachment of enveloped viruses to host cells DNJ may also be involved in altering viral surface glycoproteins so that recognition by receptor(s) on the host cell surface is altered.

Nucleopolyhedroviruses (NPVs) belong to the family Baculoviridae. NPVs are characterized by enveloped nucleocapsids and large, circular, double-stranded DNA genomes (Rohrmann, 2011). Baculoviruses have a unique biphasic replication cycle that involves the formation of two types of progeny virions: budded virus (BV) and occlusion-derived virus (ODV). $\mathrm{BV}$ is produced during an early stage of the replication cycle and obtains its envelope as it buds through the cell plasma membrane. ODV on the other hand is formed during a late stage of the replication cycle and obtains its envelope "de novo" while in the cell nucleus. The ODV is subsequently occluded in a protein matrix resulting in the formation of a granule (containing a single ODV in the case of granulovirus) or a polyhedron (containing multiple ODVs in the case of NPV). ODVs are primarily involved in insect-to-insect transmission, whereas BVs are involved in cell-to-cell transmission within a single host. A virus-encoded glycoprotein called GP64 is the major glycoprotein found in the envelope of BVs (Jarvis and Garcia 1994). GP64 is required for binding of the $\mathrm{BV}$ to a host cell and subsequent fusion of the BV envelope and endosomal membrane during the penetration phase of the virus infection cycle (Volkman et al., 1984). During a later phase of baculovirus infection, the amount of GP64 that is found in the host cell membrane is related to the efficiency of BV production and rate of systemic infection in insects (Nagai et al., 2011).

In this study, we investigated the effect of DNJ on the replication of B. mori NPV (BmNPV) and Autographa californica multiple NPV (AcMNPV). The host of BmNPV is the silkworm a specialist that feeds exclusively on mulberry, a plant with relatively high levels of DNJ. AcMNPV on the other hand replicates on generalist insects that commonly feed on plants with relatively low DNJ levels (Hirayama et al., 2007). In addition, we characterized $\alpha$-glucosidase activity in B. mori-derived Bm5 and Spodoptera frugiperda-derived $\mathrm{Sf} 9$ cell extracts. $\mathrm{Bm} 5$ and $\mathrm{Sf} 9$ are specific hosts of BmNPV and AcMNPV, respectively. We found that the replication of BmNPV on Bm5 cells was unaffected by the addition of DNJ into the culture medium, whereas AcMNPV replication on $\mathrm{Sf} 9$ cells was sensitive to DNJ in the culture medium.

\section{Materials and Methods}

\section{Chemicals}

DNJ was purified from Bacillus subtilis MORI as described previously (Kim et al., 2011). The $\alpha$-glucosidase inhibitors acarbose and voglibose were purchased from BayerKorea (Korea) and CJ (Korea), respectively. The $\alpha$-glucosidase substrate $p$-nitrophenyl $\alpha$-D-glucopyranoside (PNPG) was purchased from Sigma (USA).

\section{Cells and viruses}

Bm5 and Sf9 cells were maintained in TC-100 medium (Welgene, Korea) supplemented with $5 \%$ and $10 \%$ fetal bovine serum, respectively, at $27^{\circ} \mathrm{C}$. B. subtilis MORI was propagated in TSB medium at $37^{\circ} \mathrm{C}$ as described previously (Kim et al., 2011). BmNPV and AcMNPV were propagated on $\mathrm{Bm} 5$ and $\mathrm{Sf} 9$ cells, respectively. Viral titer was determined by the end-point dilution method as described previously (O'Reilly et al., 1992).

\section{Preparation of cell extract}

Extracts of $\mathrm{Bm} 5$ and $\mathrm{Sf} 9$ cells were prepared from $1 \times 10^{7}$ cells that were pelleted by centrifugation at $3,000 \times \mathrm{g}$ for $5 \mathrm{~min}$ at $4^{\circ} \mathrm{C}$. Following the centrifugation the cells were resuspended in $50 \mathrm{mM}$ sodium phosphate buffer ( $\mathrm{pH} 7)$ and the cells were sonicated on ice for $1 \mathrm{~min}$ using a VCX130 ultrasonic processor (Sonics \& Materials, USA). The extracts were centrifuged at $3,000 \mathrm{x}$ g for $5 \mathrm{~min}$ at $4^{\circ} \mathrm{C}$ and then stored at $-20^{\circ} \mathrm{C}$ prior to use. The protein concentration of the cell extract was measured by the method of Bradford (1976). 


\section{Virus replication assay}

$\mathrm{Bm} 5$ or Sf9 cells were seeded into the wells of a 24 well plate $\left(1 \times 10^{5}\right.$ cells per well $)$ and allowed to attach for $2 \mathrm{~h}$. Subsequently, the cells were inoculated with virus at a multiplicity of infection (MOI) of 1 . Following a 1 h-long viral attachment period, the inoculum was removed by aspiration and the cells were cultured in $0.5 \mathrm{~mL}$ of fresh medium containing $0,1,2.5,5$ or $10 \mathrm{mM}$ DNJ. After a 4 day-long incubation period at $27^{\circ} \mathrm{C}$, the virus titer in the cell culture supernatant was determined by the end-point dilution method.

\section{Cell viability assay}

Cell viability was determined using a colorimetric XTT assay (Cell Proliferation Kit; Biological industries, Israel) following the manufacturer's protocol. Bm5 or Sf9 cells were seeded into the wells of a 96 well plate $\left(1 \times 10^{4}\right.$ cells per well) and allowed to attach for $2 \mathrm{~h}$. Following cell attachment, the old cell culture supernatant was replaced with $100 \mu \mathrm{L}$ of fresh medium containing $0,1,2.5,5$ or 10 $\mathrm{mM} \mathrm{DNJ}$ and incubated at $27^{\circ} \mathrm{C}$ for $48 \mathrm{~h}$. After the $48 \mathrm{~h}$ long incubation, $50 \mu \mathrm{L}$ of activated XTT reagent was added to each well of the 96-well plate and incubated at $27^{\circ} \mathrm{C}$ for $4 \mathrm{~h}$. Subsequently, the formation of reduced XTT was measured at $450 \mathrm{~nm}$ using a microplate reader (Molecular devices, USA) as described previously (Wu et al., 2002).

\section{$\alpha$-Glucosidase activity assay}

$\alpha$-Glucosidase activity in the cell extract was measured using PNPG as a substrate in the wells of a 96 well plate. The ability of the cell extract to hydrolyze PNPG was determined in a $150 \mu \mathrm{L}$ reaction containing $80 \mu \mathrm{g}$ of cell extract and $4 \mathrm{mM}$ PNPG in $100 \mathrm{mM}$ sodium phosphate buffer, $\mathrm{pH}$ 7. The reaction mixture was incubated for 30 min at $37^{\circ} \mathrm{C}$ and then $50 \mu \mathrm{L}$ of $234 \mathrm{mM} \mathrm{Na}_{2} \mathrm{CO}_{3}$ was added to terminate the reaction. Absorbance was measured at $405 \mathrm{~nm}$ using a microplate reader as described previously (Kang et al., 2010).

The effect of $\mathrm{pH}$ on $\alpha$-glucosidase activity was determined in $100 \mathrm{mM}$ citrate buffer $(\mathrm{pH} \mathrm{3,4,5}$, and 6), $100 \mathrm{mM}$ sodium phosphate buffer $(\mathrm{pH} 7$ and 8 ) or $100 \mathrm{mM}$ glycine-NaOH buffer (pH 9, 10, 11). The effect of temperature on $\alpha$-glucosidase activity was determined in $100 \mathrm{mM}$ sodium phosphate buffer, $\mathrm{pH} 7$, at $5^{\circ} \mathrm{C}$ intervals from $25^{\circ} \mathrm{C}$ to $70^{\circ} \mathrm{C}$.

Inhibition of $\alpha$-glucosidase activity by DNJ, acarbose, and voglibose

The ability of DNJ $(0.03-1000 \mu \mathrm{M})$, acarbose $(200-$ $1,000 \mathrm{mM})$, and voglibose $(3-200 \mathrm{mM})$ to inhibit $\alpha$-glucosidase in Bm5 and $\mathrm{Sf} 9$ cell extracts was determined using PNPG as a substrate in $100 \mathrm{mM}$ sodium phosphate buffer, $\mathrm{pH} 7$, as described above. Each inhibitor, dissolved in water, was preincubated with the $\mathrm{Bm} 5$ or $\mathrm{Sf} 9$ cell extract for $5 \mathrm{~min}$ at $37^{\circ} \mathrm{C}$ prior to the addition of PNPG. Following the addition of the PNPG, the reaction was incubated for $30 \mathrm{~min}$ at $37^{\circ} \mathrm{C}$ and then read at $405 \mathrm{~nm}$ as described above. The median inhibitory concentration $\left(\mathrm{IC}_{50}\right)$ of each compound was determined by regression analysis (SigmaPlot; SPSS Scientific, USA).

\section{Results}

\section{Effect of DNJ on the replication of BmNPV and AcMNPV}

DNJ is a known inhibitor of $\alpha$-glucosidase activity as well as the replication of various viruses. The ability of DNJ to inhibit the replication of BmNPV and AcMNPV was determined in $\mathrm{Bm} 5$ and $\mathrm{Sf} 9$ cells that were grown in medium containing 1 to $10 \mathrm{mM}$ DNJ. After 4 days, DNJ showed no significant effect on BmNPV replication in $\mathrm{Bm} 5$ cells at a concentration as high as $10 \mathrm{mM}$ (Fig. 1). In contrast, AcMNPV replication was significantly reduced in the presence of $2.5 \mathrm{mM}$ or higher concentrations of

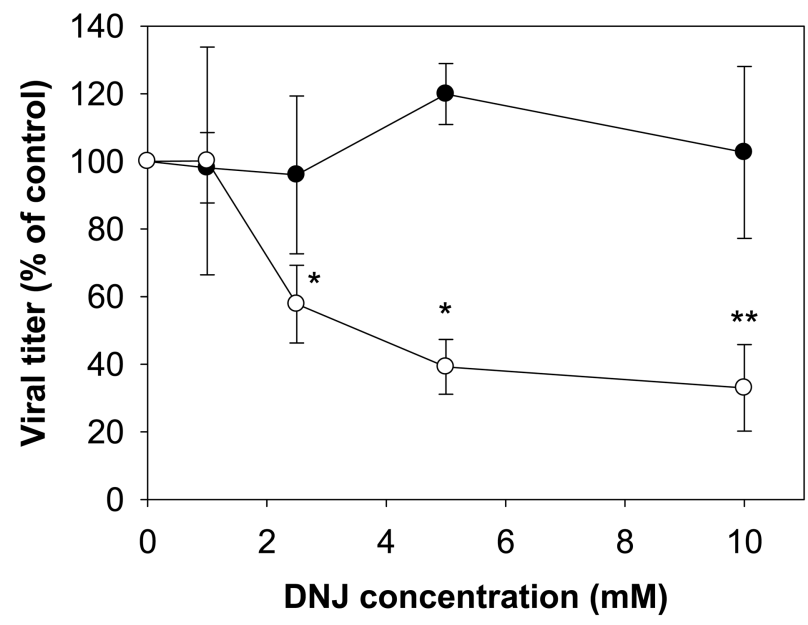

Fig. 1. The effect of DNJ on the replication of BmNPV ( and AcMNPV $(\bigcirc)$. Bm5 or Sf9 cells were inoculated with BmNPV or AcMNPV, respectively, at an MOI of 1. Following inoculation, the cells were maintained in medium containing 0 , $1,2.5,5$ or $10 \mathrm{mM}$ DNJ. At 4 days postinfection, the viral titer in each of the DNJ containing treatments was determined and compared to the viral titers in non-DNJ containing control infections. Each point represents the mean value of three independent experiments. The error bars indicate standard deviation of the mean. The asterisk indicates a significant difference between the mean viral titer in non-treated and DNJ-treated groups $(* P<0.05, * * P<0.01)$. 


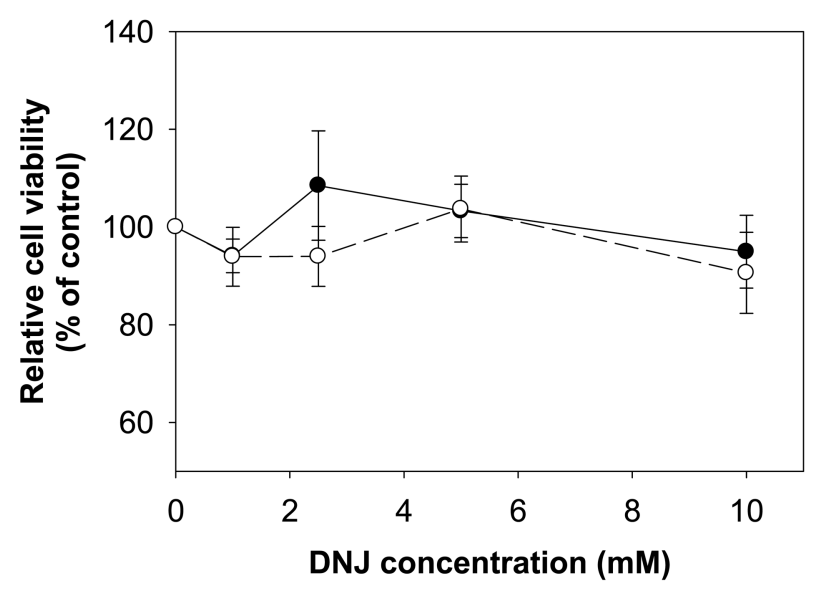

Fig. 2. Viability of Bm5 (०) and Sf9 $(\bigcirc)$ cells following treatment with DNJ. The viability of cells that were grown for $48 \mathrm{~h}$ in medium containing $0,1,2.5,5$ or $10 \mathrm{mM}$ DNJ was compared to the viability of control cells that were grown in medium lacking DNJ. Cell viability was measured using XTT reagent. Each point represents the mean value of three independent experiments. The error bars indicate standard deviation of the mean. No statistically significant differences were found between cells grown in the absence or presence of DNJ up to $10 \mathrm{mM}$.

DNJ (in comparison to control Sf9 cells that were not treated with DNJ). AcMNPV showed a dose-specific inhibitory response up to $5 \mathrm{mM}$ DNJ (i.e., no apparent inhibition at $1 \mathrm{mM}$ DNJ, $40 \%$ inhibition at $2.5 \mathrm{mM}$ DNJ, and $60 \%$ inhibition at $5 \mathrm{mM} \mathrm{DNJ}$ ). The replication of AcMNPV, at 4 days post inoculation, was inhibited by approximately $67 \%$ when the host $\mathrm{Sf} 9$ cells were grown in medium containing $10 \mathrm{mM}$ DNJ.

\section{Effect of DNJ on the viability of Bm5 and Sf9 cells}

The viability of $\mathrm{Bm} 5$ and $\mathrm{Sf} 9$ cells was measured by the colorimetric XTT assay. DNJ did not show any statistically significant affects on the viability of $\mathrm{Bm} 5$ and $\mathrm{Sf} 9$ cells that were grown for $48 \mathrm{~h}$ in medium containing up to $10 \mathrm{mM}$ DNJ (Fig. 2). The results indicated that the viability of Bm5 and Sf9 cells is not affected by DNJ.

Effect of $\mathrm{pH}$ and temperature on $\alpha$-glucosidase activity from $\mathrm{Bm} 5$ and $\mathrm{Sf} 9$ cell extracts

$\alpha$-Glucosidase activity in Bm5 and Sf9 cell extracts was measured using PNPG as a substrate in $100 \mathrm{mM}$ sodium phosphate buffer, $\mathrm{pH} 7$. Under this condition $\alpha$-glucosidase specific activity in the $\mathrm{Sf} 9$ cell extract $(3.39 \mu \mathrm{mol} /$ $\mathrm{min} / \mathrm{mg}$ ) was roughly 2-fold higher than that in the Bm5 cell extract $(1.73 \mu \mathrm{mol} / \mathrm{min} / \mathrm{mg})$ (Table 1$)$. When the effect of $\mathrm{pH}$ on $\alpha$-glucosidase activity was analyzed, the highest activity in both $\mathrm{Bm} 5$ and Sf9 cell extracts was
Table 1. $\alpha$-Glucosidase activity in extracts from $\mathrm{Bm} 5$ and Sf9 cells

\begin{tabular}{cc}
\hline Extract source & $\begin{array}{c}\text { Specific activity } \\
(\mu \mathrm{mol} / \mathrm{min} / \mathrm{mg} \text { protein })^{\mathrm{a}}\end{array}$ \\
\hline Bm5 & $1.73 \pm 0.42^{\mathrm{b}}$ \\
Sf9 & $3.39 \pm 0.58$ \\
\hline
\end{tabular}

$\bar{a} p$-Nitrophenyl $\alpha$-D-glucopyranoside was used as a substrate to measure $\alpha$-glucosidase activity in $100 \mathrm{mM}$ sodium phosphate buffer, $\mathrm{pH} 7$.

${ }^{\mathrm{b}}$ Values represent the mean \pm standard deviation separate experiments.

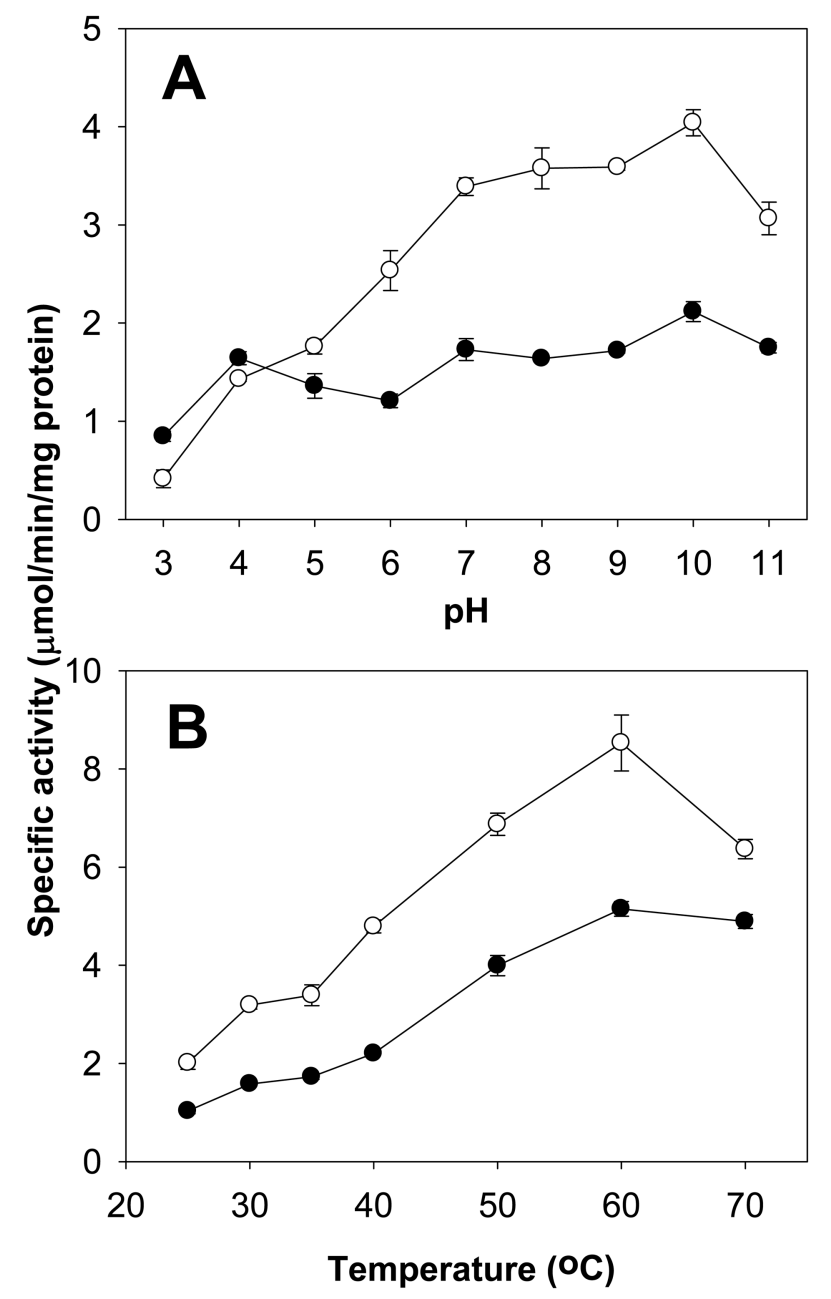

Fig. 3. The effect of $\mathrm{pH}(\mathrm{A})$ and temperature (B) on $\alpha$-glucosidase activity in extracts of $\mathrm{Bm} 5(\mathbf{O})$ and $\mathrm{Sf} 9(\bigcirc)$ cells. The $\alpha-$ glucosidase activity was measured with $p$-nitrophenyl $\alpha$-Dglucopyranoside substrate. Each point represents the mean value of three experiments. The error bars indicate standard deviation of the mean.

found at $\mathrm{pH} 10$ (Fig. 3A). In comparison to the $\mathrm{Bm} 5$ cell extract, $\alpha$-glucosidase activity in the $\mathrm{Sf} 9$ cell extract 
Table 2. Inhibition of $\alpha$-glucosidase activity in Bm5 and Sf9 cell extracts by DNJ, acarbose, and voglibose

\begin{tabular}{cccc}
\hline \multirow{2}{*}{ Extract source } & \multicolumn{3}{c}{$\mathrm{IC}_{50}(\mu \mathrm{M})^{\mathrm{a}}$} \\
\cline { 2 - 4 } & $\mathrm{DNJ}$ & acarbose & voglibose \\
\hline Bm5 & $26.1 \pm 3.0^{\mathrm{b}}$ & $\mathrm{NI}^{\mathrm{c}}$ & $27.9 \pm 2.1$ \\
Sf9 & $0.64 \pm 0.06$ & $\mathrm{NI}$ & $13.3 \pm 4.0$ \\
\hline
\end{tabular}

$\overline{{ }^{a} p \text {-Nitrophenyl } \alpha \text {-D- glucopyranoside was used as a substrate }}$ to measure $\alpha$-glucosidase activity in $100 \mathrm{mM}$ sodium phosphate buffer, $\mathrm{pH} 7$.

${ }^{b}$ Values represent the mean a standard error of three separate experiments.

${ }^{\mathrm{c} N I}$ : No Inhibition (less than $50 \%$ inhibition at $1000 \mu \mathrm{M}$ ).

showed greater sensitivity to increases in $\mathrm{pH}$. $\alpha$-Glucosidase activity in the Bm5 cell extract showed relatively little sensitivity to changes in $\mathrm{pH}$. Surprisingly, $\alpha$ glucosidase activity in the $\mathrm{Bm} 5$ and $\mathrm{Sf} 9$ cell extracts showed strong thermo stability with increased activity up to $60^{\circ} \mathrm{C}$ (Fig. 3B).

Inhibition of $\alpha$-glucosidase activity in $\mathrm{Bm5}$ and $\mathrm{Sf} 9$ cell extracts by DNJ, acarbose, and voglibose

The ability of DNJ, acarbose, and voglibose to inhibit $\alpha$ glucosidase activity in Bm5 and $\mathrm{Sf} 9$ cell extracts was measured using PNPG as a substrate in $100 \mathrm{mM}$ sodium phosphate buffer, $\mathrm{pH}$ 7. $\alpha$-Glucosidase activity in the $\mathrm{Sf} 9$ cell extract was 40 -fold more sensitive to DNJ than $\alpha$ glucosidase activity in the Bm5 cell extract (Table 2). Similarly, $\alpha$-glucosidase activity in the Sf9 cell extract was more sensitive to inhibition by voglibose but by only 2 -fold in comparison to $\alpha$-glucosidase activity in the Bm5 cell extract (Table 2). Acarbose did not show any detectable inhibitory activity with $\mathrm{Bm} 5$ and $\mathrm{Sf9}$ cell extracts.

\section{Discussion}

$\alpha$-Glucosidase I removes the terminal glucose residue of $\mathrm{Glc}_{3} \mathrm{Man}_{9} \mathrm{GlcNAc}_{2}$ that is attached to a nascent glycoproteins, a critical initial step of the $N$-linked glycosylation process. The inhibition of $\alpha$-glucosidase interrupts the maturation of glycoproteins that are found on the envelope of enveloped viruses resulting in reduced viral particle assembly, suppression of virion secretion, and interference of the attachment of virions to host cells (Pelletier et al., 2000; Jacob et al., 2007). DNJ is an iminosugar which can competitively inhibit $\alpha$-glucosidase I and II in the ER (Moremen et al., 1994; Wojczyk et al., 1995). Inhibition of the formation of mature virions and reduced infectivity have been found in enveloped viruses such as HBV, human immunodeficiency virus (HIV), herpes simplex virus type 1, influenza virus, bovine viral diarrhea virus (BVDV), dengue virus (DENV), West Nile virus (WNV), Japanese encephalitis virus, and HCV following exposure to DNJ and its derivatives (Durantel et al., 2001; Dwek et al., 2002; Mehta et al., 2002; Woodhouse et al., 2008). In this study, we found that the presence of DNJ reduces the budded virus titer of AcMNPV but not BmNPV. This suggested that $\alpha$-glucosidase activity that processes the glycoproteins of AcMNPV is dramatically more sensitive to DNJ.

In our previous work, we showed that $\alpha$-glucosidase activity in the midgut of $B$. mori, a specialist insect that feeds exclusively on mulberry leaf, is less sensitive to DNJ in comparison to $\alpha$-glucosidase activity in the midgut of Antheraea yamamai, a generalist insect (Kang et al., 2010). Hirayama et al. (2007) have also shown that sucrase and trehalase in the midgut of $B$. mori are less sensitive to DNJ in comparison to the corresponding enzymes of Samia ricini, a generalist herbivore. We found similar results in this study. The sensitivity of $\alpha$-glucosidase activity in the $\mathrm{Bm} 5$ cell extract was significantly lower (i.e., 40-fold higher $\mathrm{IC}_{50}$ ) in comparison to that found in the Sf9 cell extract when PNPG, a known substrate of $\alpha$-glucosidase II (Moremen et al., 1994), was used as a substrate. Since it appeared that DNJ did not induce any effects on cell viability, we hypothesized that the reduction in AcMNPV titer that was found in Sf9 cells grown in DNJ containing medium resulted from the inhibition of $\alpha$-glucosidase I and/or $\alpha$-glucosidase II that are important for the formation and/or release of mature BVs. In contrast, in Bm5 cells these enzymes appeared to be less sensitive to the effects of DNJ, so that the formation and/or release of BmNPV BVs from Bm5 cells that were grown in DNJ containing medium was unaffected. Our findings are the first to show a differential response in terms of the inhibitory effects of DNJ on $\alpha$-glycosidase activity in insects and on the ability of baculoviruses to efficiently replicate. Elucidation of the molecular mechanism behind this differential sensitivity to DNJ will provide a probe for the study of the comparative evolution of insects and nucleopolyhedroviruses.

\section{Acknowledgment}

This research (\#70011060) was financially supported by the Ministry of Knowledge and Economy (MKE) and Korea Institute for Advancement of Technology (KIAT) through the Research and Development for Regional Industry. 


\section{References}

Asano N, Yamashita T, Yasuda K, Ikeda K, Kizu H, Kameda Y, Kato A, Nash RJ, Lee HS, Ryu KS (2001) Polyhydroxylated alkaloids isolated from mulberry trees (Morus alba L.) and silkworms (Bombyx mori L.). J Agric Food Chem 49, 42084213.

Bradford MM (1976) A rapid and sensitive method for the quantitation of microgram quantities of protein utilizing the principle of protein-dye binding. Anal Biochem 72, 248-254.

Durantel D, Branza-Nichita N, Carrouee-Durantel S, Butters TD, Dwek RA, Zitzmann N (2001) Study of the mechanism of antiviral action of iminosugar derivatives against bovine viral diarrhea virus. J Virol 75, 8987-8998.

Dwek RA, Butters TD, Platt FM, Zitzmann N (2002) Targeting glycosylation as a therapeutic approach. Nat Rev Drug Discov 1, 65-75.

Francis BR, Paquin L, Weinkauf C, Jarvis DL (2002) Biosynthesis and processing of Spodoptera frugiperda alpha-mannosidase III. Glycobiology 12, 369-377.

Hirayama C, Konno K, Wasano N, Nakamura M (2007) Differential effects of sugar-mimic alkaloids in mulberry latex on sugar metabolism and disaccharidases of Eri and domesticated silkworms: enzymatic adaptation of Bombyx mori to mulberry defense. Insect Biochem Mol Biol 37, 1348-1358.

Jacob JR, Mansfield K, You JE, Tennant BC, Kim YH (2007) Natural iminosugar derivatives of 1-deoxynojirimycin inhibit glycosylation of hepatitis viral envelope proteins. J Microbiol 45, 431-440.

Jarvis DL, Garcia A, Jr. (1994) Biosynthesis and processing of the Autographa californica nuclear polyhedrosis virus gp64 protein. Virology 205, 300-313.

Kang K-D, Kamita SG, Suzuki K, Seong SI (2010) Comparative analysis of $\alpha$-glucosidase activity in Bombyx mori and Antheraea yamamai. Int J Indust Entomol 21, 163-167.

Kim HS, Lee JY, Hwang KY, Cho YS, Park YS, Kang K-D, Seong SI (2011) Isolation and identification of a Bacillus sp. producing $\alpha$-glucosidase inhibitor 1-deoxynojirimycin. Korean J Microbiol Biotechnol 39, 49-55.

Mehta A, Ouzounov S, Jordan R, Simsek E, Lu X, Moriarty RM, Jacob G, Dwek RA, Block TM (2002) Imino sugars that are less toxic but more potent as antivirals, in vitro, compared with N-n-nonyl DNJ. Antivir Chem Chemother 13,
299-304.

Moremen KW, Trimble RB, Herscovics A (1994) Glycosidases of the asparagine-linked oligosaccharide processing pathway. Glycobiology 4, 113-125.

Nagai S, Alves CA, Kobayashi M, Ikeda M (2011) Comparative transient expression assay analysis of hycu-hr6- and IE1-dependent regulation of baculovirus gp64 early promoters in three insect cell lines. Virus Res 155, 83-90.

O'Reilly DR, Miller LK, Luckow VA (1992) Baculovirus expression vectors: a laboratory manual. Oxford University Press, New York.

Pelletier MF, Marcil A, Sevigny G, Jakob CA, Tessier DC, Chevet E, Menard R, Bergeron JJ. Thomas DY (2000) The heterodimeric structure of glucosidase II is required for its activity, solubility, and localization in vivo. Glycobiology $10,815-827$.

Ren J, Castellino FJ, Bretthauer RK (1997) Purification and properties of alpha-mannosidase II from Golgi-like membranes of baculovirus-infected Spodoptera frugiperda (IPLB-SF-21AE) cells. Biochem J 324, 951-956.

Rohrmann, GF (2011) Baculovirus Molecular Biology. 2nd Ed. Bethesda (MD): National Library of Medicine (US).

Summers MD (2006) Milestones leading to the genetic engineering of baculoviruses as expression vector systems and viral pesticides. Adv Virus Res 68, 3-73.

Volkman LE, Goldsmith PA, Hess RT, Faulkner P (1984) Neutralization of budded Autographa californica NPV by a monoclonal antibody: identification of the target antigen. Virology 133, 354-362.

Wojczyk B, Shakin-Eshleman SH, Doms RW, Xiang ZQ, Ertl HC, Wunner WH, Spitalnik SL (1995) Stable secretion of a soluble, oligomeric form of rabies virus glycoprotein: influence of N-glycan processing on secretion. Biochemistry 34, 2599-2609.

Woodhouse SD, Smith C, Michelet M, Branza-Nichita N, Hussey M, Dwek RA, Zitzmann N (2008) Iminosugars in combination with interferon and ribavirin permanently eradicate noncytopathic bovine viral diarrhea virus from persistently infected cells. Antimicrob Agents Chemother 52, 18201828.

Wu SF, Lee CJ, Liao CL, Dwek RA, Zitzmann N, Lin YL (2002) Antiviral effects of an iminosugar derivative on flavivirus infections. J Virol 76, 3596-3604. 